\title{
Spatial analysis of early mangrove regeneration in the Matang Mangrove Forest Reserve, Peninsular Malaysia, using geomatics
}

\author{
Viviana Otero $^{\mathrm{a}, *}$, Richard Lucas ${ }^{\mathrm{b}, \mathrm{c}}$, Ruben Van De Kerchove ${ }^{\mathrm{d}}$, Behara Satyanarayana ${ }^{\mathrm{a}, \mathrm{e}}$, \\ Husain Mohd-Lokman ${ }^{\mathrm{e}}$, Farid Dahdouh-Guebas ${ }^{\mathrm{a}, \mathrm{f}}$ \\ ${ }^{a}$ Systems Ecology and Resource Management Laboratory, Université Libre de Bruxelles (ULB), Brussels, Belgium \\ ${ }^{\mathrm{b}}$ Earth Observation and Ecosystem Dynamics Research Group, Aberystwyth University, Aberystwyth, UK \\ ${ }^{\mathrm{c}}$ School of Biological, Earth and Environmental Sciences, University of New South Wales (UNSW), Sydney, Australia \\ ${ }^{\mathrm{d}}$ Vlaamse Instelling Voor Technologisch Onderzoek (VITO) Research Organisation, Mol, Belgium \\ ${ }^{\mathrm{e}}$ Mangrove Research Unit, Institute of Oceanography and Environment, Universiti Malaysia Terengganu (UMT), Kuala Nerus, Terengganu, Malaysia \\ ${ }_{\mathrm{f}}^{\mathrm{f}}$ Ecology \& Biodiversity, Laboratory of Plant Biology and Nature Management, Vrije Universiteit Brussel (VUB), Brussels, Belgium
}

\section{A R T I C L E I N F O}

\section{Keywords:}

Mangroves

Mangrove regeneration

Silviculture

Spatial analysis

\begin{abstract}
A B S T R A C T
Successful mangrove tree regeneration is required to maintain the provision of wood for silviculturally managed mangrove forest areas and to ensure mangrove rehabilitation in disturbed areas. Successful natural regeneration of mangroves after disturbance depends on the dispersal, establishment, early growth and survival of propagules. Focusing on the Matang Mangrove Forest Reserve (MMFR) in Peninsular Malaysia, we investigated how the location of a mangrove forest patch might influence the early regeneration of mangroves after clear-felling events that regularly take place on an approximately 30-year rotation as part of local management. We used Landsat-derived Normalized Difference Moisture Index (NDMI) annual time series from 1988 to 2015 to indicate the recovery of canopy cover during early regeneration, which was determined as the average time (in years) for the NDMI to recover to values associated with the mature forests prior to their clear felling. We found that clearfelled mangrove patches closer to water and/or to already established patches of Rhizophora regenerated more rapidly than those farther away. In contrast, patches located closer to dryland forests regenerated slower compared to patches that were farther away. The study concludes that knowledge of the distribution of water, hydro-period and vegetation communities across the landscape can indicate the likely regeneration of mangrove forests through natural processes and identify areas where active planting is needed. Furthermore, time-series comparisons of the NDMI during the early years of regeneration can assist monitoring of mangrove establishment and regeneration, inform on the success of replanting, and facilitate higher productivity within the MMFR.
\end{abstract}

\section{Introduction}

Mangroves are woody plants found in intertidal zones in tropical and subtropical latitudes along bays, estuaries, lagoons, and backwaters (Mukherjee et al., 2014, Duke et al., 1998). Mangrove forests provide ecosystem services such as provision of wood and fuelwood, non-timber forest products, fisheries, coastal protection, sediment trapping, carbon storage, biodiversity, aesthetic and recreational values (DahdouhGuebas et al., 2006; Walters et al., 2008, Donato et al., 2011, Alongi, 2012, Feller et al., 2017, Tomlinson, 2016). As a consequence of the traditional use of timber and poles, silviculture, among others, has been one of the primary drivers behind many mangrove restoration projects
(Saenger 2002, Bosire et al., 2008, Ellison, 2000, López-Portillo, 2017). Before 1982, the purpose of silviculture for mangrove forests management was mainly focused on wood extraction for commercial purposes through establishment of plantations (Spalding et al., 2010, Saenger, 2002, Ellison, 2000). From 1982 onwards, the purpose of mangrove management has gradually changed towards the conservation and rehabilitation of mangrove ecosystems (Ellison, 2000).

Successful mangrove tree regeneration is required to ensure a sustainable silvicultural management in order to maintain the provision of wood. Natural regeneration of mangroves after a disturbance depends on the dispersal, establishment, early growth and survival of propagules and seedlings (Di Nitto et al., 2013, Sillanpää et al., 2017, Tomlinson,

Abbreviations: GLS, Generalized Least Squares; MMFR, Matang Mangrove Forest Reserve; NDMI, Normalized Difference Moisture Index; NDVI, Normalized Difference Vegetation Index; SD, Standard Deviation; SPOT, Satellite Pour l'Observation de la Terre; UTM, Universal Transverse Mercator

* Corresponding author at: Avenue F.D. Roosevelt 50, CPI 264/1, B-1050 Brussels, Belgium.

E-mail address: voterofa@ulb.ac.be (V. Otero). 

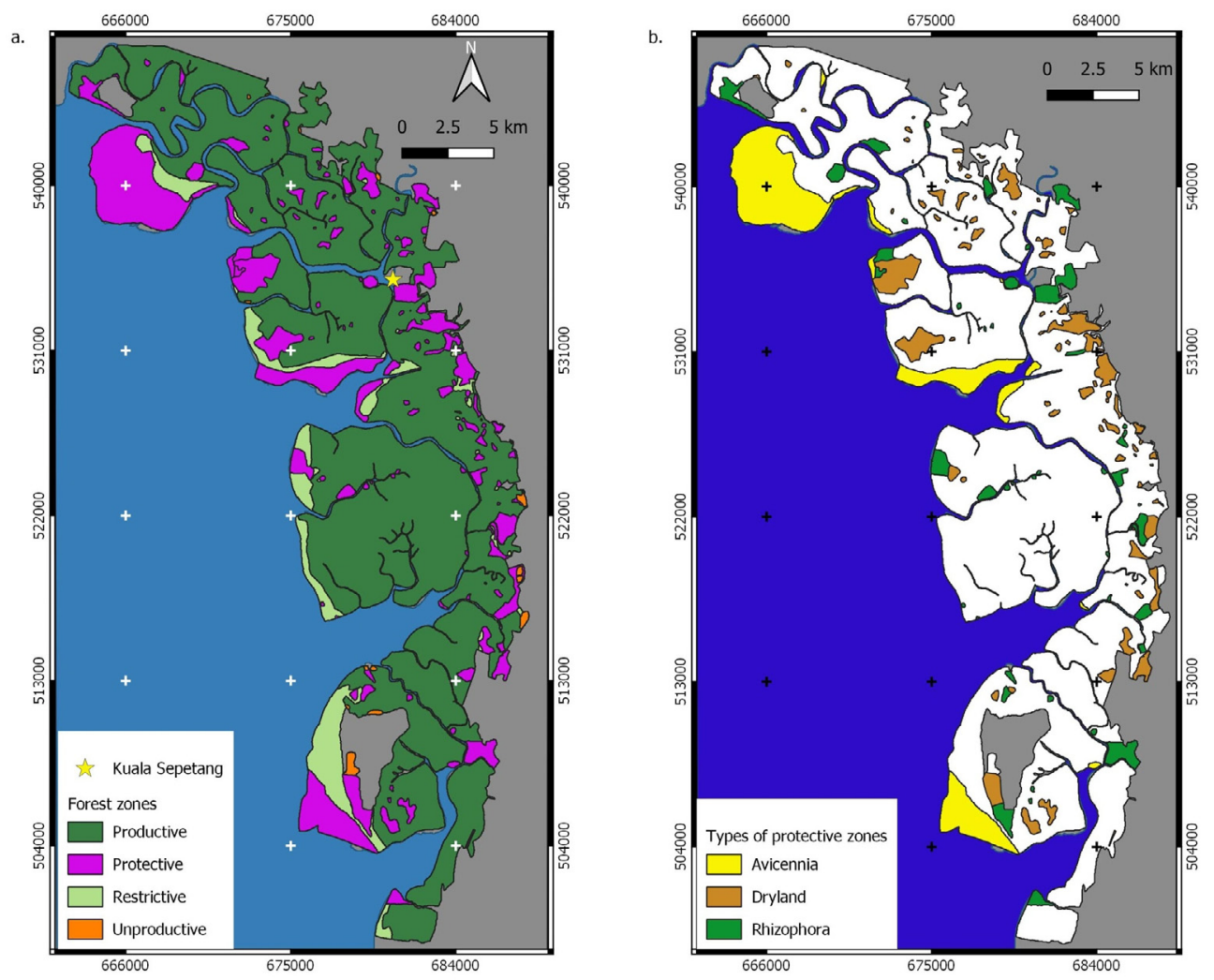

Fig. 1. (a) The management zones of the MMFR on the west coast of Peninsular Malaysia (based on Ariffin and Mustafa, 2013, Otero et al., 2019), with these referred to as productive, restrictive productive, protective and unproductive zones (Taken from Otero et al., 2019). The species composition of each zone differs, with the productive and restrictive productive zones comprised primarily of $R$. apiculata and $R$. mucronata species. (b) The protective zones are more diverse in terms of mangrove species composition. Within the protective zones, the main types of forest occurring are Avicennia-Sonneratia stands, Rhizophora stands and the dryland forest stands (based on Ariffin and Mustafa, 2013). The grey areas represent areas outside of the reserve.

2016). Propagule dispersal requires a normal tidal flooding and sufficient propagules in adjacent mangrove stands (Bosire et al., 2008, Kairo et al., 2001, Lewis, 2005) and, as with establishment, are affected by factors such as wind speed, freshwater discharge, geomorphology, trapping agents, propagule morphology, propagule predation, light and nutrient availability (Di Nitto et al., 2013, Komiyama et al., 1996, Sousa et al., 2007; Tomlinson, 2016, Van der Stocken et al., 2015, Van Nedervelde et al., 2015).

Spatial information on the extent, state and dynamics of coastal environments is important for understanding the recovery of mangroves following disturbance (Rivera-Monroy et al., 2004) and other biological processes (Hickey et al., 2018, Koch et al., 2009, Ribeiro et al., 2009). Remote sensing data can provide such information over varying (e.g. sub-annual to multi-decadal) spatial and temporal scales (Camarretta et al., 2017, Herold et al., 2005, Hickey et al., 2018). As such, these data have been used for land cover classification, species mapping, biomass, landscape metrics calculation and disturbance detection (e.g. Amir, 2012, Aslan et al., 2016, Bunting et al., 2018, Conchedda et al., 2008, Hamunyela et al., 2016, Hickey et al., 2018, Simard et al., 2019, Suyadi et al., 2018). Whereas few studies have used spatial information extracted from remote sensing to study spatial trends in mangrove regeneration (Suyadi et al., 2018, Hickey et al., 2018), regeneration has been mainly studied with field-based approaches (e.g. Kairo et al., 2001, Bosire et al., 2005; Lewis, 2005, Peng et al., 2016, Putz and Chan, 1986, Sillanpää et al., 2017, Sousa et al., 2003; Sousa et al., 2007).

The Matang Mangrove Forest Reserve (MMFR), located in the West Coast of Peninsular Malaysia, has been managed for charcoal and pole production since 1902 (Chong, 2006). Although, mangrove regeneration at MMFR has been studied using ground-based forest inventories (e.g. Amir, 2012, Goessens et al., 2014, Gong and Ong, 1995, Putz and Chan, 1986), the use of remote sensing data and the relationship between regeneration and proximity to other types of land cover has received less attention. Moreover, Aziz et al. $(2015,2016)$ identified that some areas in the MMFR experienced different regeneration rates, which can impact the greenwood yield and carbon sequestration in the reserve. Therefore, it is useful for the local management to have the information about which areas have different regeneration rates and which factors could explain the differences. Therefore, this study aimed to (i) establish whether forest regeneration rates varied within and between forest patches that were clear felled and, if so, (ii) whether recovery varied as a function of proximity of the cleared area to water or to other mangrove forests based on their species dominance.

\section{Materials and methods}

\subsection{Study area}

The MMFR is one of the most known cases of mangrove silvicultural management world-wide (FAO, 1994, Saenger, 2002, Friess et al., 2016). The reserve is a riverine mangrove forest of 27 different true mangrove species and provides ecosystem services such as wood provision for charcoal and pole production, coastal protection, conservation of flora and fauna, ecotourism, fishery maintenance and mangrove propagule production (Ariffin and Mustafa, 2013). The MMFR occupies an area of 40,288 ha and has a tropical climate with an average air temperature ranging from $22{ }^{\circ} \mathrm{C}$ to $33{ }^{\circ} \mathrm{C}$ (Ariffin and Mustafa, 2013). The rainfall rate is between $2,000 \mathrm{~mm}$ and $2,800 \mathrm{~mm}$ per year (Ariffin and Mustafa, 2013). Tides are semidiurnal with an amplitude of $3.3 \mathrm{~m}$ (Asthon et al., 1999). Medium height tides inundate Rhizophora stands that are near the tidal creeks (Ariffin and Mustafa, 2013). Normal height tides inundate extensive central mangrove areas that are normally composed by Rhizophora and Bruguiera spp. (Ariffin and Mustafa, 2013).

The MMFR is divided into four different administrative zones: protective (17.4\% of the total forest area in the Reserve), productive (74.8\%), restrictive productive (6.8\%) and unproductive (1\%) (Fig. 1a) (Ariffin and Mustafa, 2013). The productive and restrictive productive zones are exploited for timber extraction to produce charcoal and poles. These zones are composed of forests dominated primarily by Rhizophora 
apiculata Bl. and Rhizophora mucronata Lamk. The current silvicultural management consists of a 30 -year rotation cycle with two thinnings at 15 and 20 years (Ariffin and Mustafa, 2013, Chong, 2006). The protective zones are not intended to provide wood for charcoal and pole production. The unproductive zones are lakes and infrastructure areas, including urban villages, charcoal kilns and offices (Ariffin and Mustafa, 2013).

The protective zones are composed of different mangrove formation communities (Fig. 1) (Ariffin and Mustafa, 2013): (i) Avicennia-Sonneratia stands, (ii) Rhizophora stands and (iii) the dryland forest stands (Fig. 1b). (i) The Avicennia-Sonneratia stands are typically composed of young stands of Avicennia trees that are colonising the new mudflats at river mouth. The dominant species in these stands are Avicennia alba Blume and Avicennia officinalis L., although it is also possible to find patches of Sonneratia alba J. Smith within the clusters of $A$. alba and $A$. officinalis. These stands are inundated by all high tides (loc.cit.). The size of these stands is 3299 ha (loc.cit.). (ii) The Rhizophora stands within the protective zone are formations of $R$. apiculata and $R$. mucronata that are not under exploitation. Whereas R. apiculata is the dominant species, $R$. mucronata can be found along the banks of the tidal creeks and streams (loc.cit.). The size of these stands is 1665 ha (iii) The dryland forest stands are the transition to inland forest. These stands are characterised by the predominance of dense patches of Acrostichum aureum Linnaeus on the forest floor with scattered pockets of dryland trees (Ariffin and Mustafa, 2013).

Dryland forests stands are composed of 30 different tree species (Chan, 1989). Four out of the thirty tree species are major and minor elements of mangroves according to Tomlinson (2016) (see supplementary data Table S1). The dryland forest stands are inundated by equinoctial tides and are found in more elevated areas in the landward side. The dryland forest stands size is 2291 ha (Ariffin and Mustafa, 2013). The maps of the administrative zones and types of protective zones (Fig. 1) were digitized and georeferenced based on the corresponding maps printed in the management plan from 2010 to 2019. The dominant species composition for the protective zones is also based on the description indicated in the local management plan (Ariffin and Mustafa, 2013).

The management plan of the reserve is defined every ten years and includes the planning of the thinning and clear-felling activities. The clear-felling activities are performed by approved charcoal contractors, who can choose the areas that they are going to harvest according to an order pre-defined via balloting (Ariffin and Mustafa, 2013, p. 48). The assignment of the areas to be clear-felled by certain contractors are included in the management plan as are maps that indicate the year when certain areas are planned to be cut. Each contractor receives an area between 2.2 ha and 6.6 ha to clearfell and extract wood to produce charcoal (Ariffin and Mustafa, 2013). The contractors are obliged to fell both the commercial (R. apiculata and R. mucronata) and non-commercial species (Bruguiera parviflora Wight \& Arnold ex Griffith and Bruguiera cylindrica (Linnaeus) Blume). In addition, the Forestry Department is in charge of weeding operations in recently clear-felled areas that have been colonized by Acrostichum ferns (Ariffin and Mustafa, 2013, p. 58).

The management implements a policy of active replanting, which is performed by qualified contractors who source and plant propagules (Ariffin and Mustafa, 2013, p. 53). The traditional method for replanting is to plant propagules directly. Planting using seedlings grown in plastic bags is used for problematic areas, that are areas deeply flooded, contain significant populations of crabs and monkeys, or are contained within the restrictive productive zones (Ariffin and Mustafa, 2013, p. 53). The decision on where to replant is based on the assessment of all clear-felled areas two years after a clear-felling event. If the natural regeneration is less than $90 \%$, Rhizophora propagules or seedlings (for problematic areas) are planted where needed (Ariffin and Mustafa, 2013, p. 55). Although this is the reported strategy, we were informed that the current reference for replanting is less than $70 \%$ instead of $90 \%$ (March 2019 by personal communication with a local forest department officer). $R$. apiculata propagules are planted at a spacing of $1.2 \mathrm{~m} \times 1.2 \mathrm{~m}$, and $R$. mucronata propagules are planted at a spacing of $1.8 \mathrm{~m} \times 1.8 \mathrm{~m}$ (Ariffin and Mustafa, 2013, p. 55). Nomenclature of mangrove species and associates followed Tomlinson (2016).

\subsection{Mangrove regeneration}

In this study, we focus on the period of regeneration between the clearing event and the attainment of an areal canopy cover that is broadly equivalent to that associated with the mature forests prior to clearing. On this basis, we quantify the early recovery based on the Normalized Difference Moisture Index (NDMI) time series (Otero et al., 2019). The NDMI time series, was created based on annual images from 1988 to 2015, using Landsat Surface Reflectance level 2 data products that were downloaded from the United Stated Geological Survey (USGS) Earth Explorer site (Otero et al., 2019). A single image per year was obtained based on cloud-free scenes or composites of several scenes within one year. Based on the annual image, the corresponding NDMI index was created based on the following equation (Gao, 1996):

$\mathrm{NDMI}=(\mathrm{NIR}-\mathrm{SWIR}) /(\mathrm{NIR}+\mathrm{SWIR})$

where NIR is the Near-Infrared band and SWIR is the short-wave infrared band. We used the NDMI vegetation index as this has been shown to be indicative of percentage canopy cover (Lucas et al., 2020). The early recovery time was defined as the number of years that the NDMI recovered to values observed prior to the clear-felling event. Therefore, only the first years of mangrove regeneration are quantified as the NDMI vegetation index saturates in dense vegetation (see Otero et al., 2019 for more details).

Additionally, the map that contained the information of the year of clear felling (from Otero et al., 2019) was used to define the extent of the coupes, with each representing an area of mangrove forest that was clear felled in the same year. The recovery time was considered for each $30 \mathrm{~m}$ pixel associated with the Landsat sensor data and associated NDMI time series (Otero et al., 2019).

\subsection{Distance calculation}

For each coupe defined using a pre-determined clear-felling map (Otero et al., 2019), the centre of each coupe was calculated using the Centroids tool available in QGIS (QGIS Development Team, 2018). Afterwards, for each centre, the following information was extracted (Fig. 2):

2.3.1. The coordinates of the centre projected in the Universal Transverse Mercator (UTM) Zone $47 \mathrm{~N}$, with each assigned with a unique ID

2.3.2. The primary year of clear-felling for each coupe, based on Otero et al. (2019), noting that some coupes mapped in the management plan can be cleared over 2 or more years (Lucas et al., 2020) and hence the area of coupes created in a year may differ from that in the management plan.

2.3.3. The average and standard deviation of recovery time based on all the pixels within each identified coupe. This recovery time was defined as the number of years that the NDMI recovered to values observed prior to the clear-felling event (Otero et al., 2019).

2.3.4. The straight-line distance to the closest water body (i.e., sea, tidal creeks) based on a water mask, which was created from Landsat sensor data from 1988 to 2015 with the Normalized Difference Vegetation Index (NDVI) time series (from Otero et al., 2019).

2.3.5. The distance to the closest Rhizophora stand, which was determined from two existing maps: (i) the management plan map that describes the protective zones and indicates the location of Rhizophora stands in these zones (green areas in Fig. 1b), and (ii) the management plan map that describes the productive and 


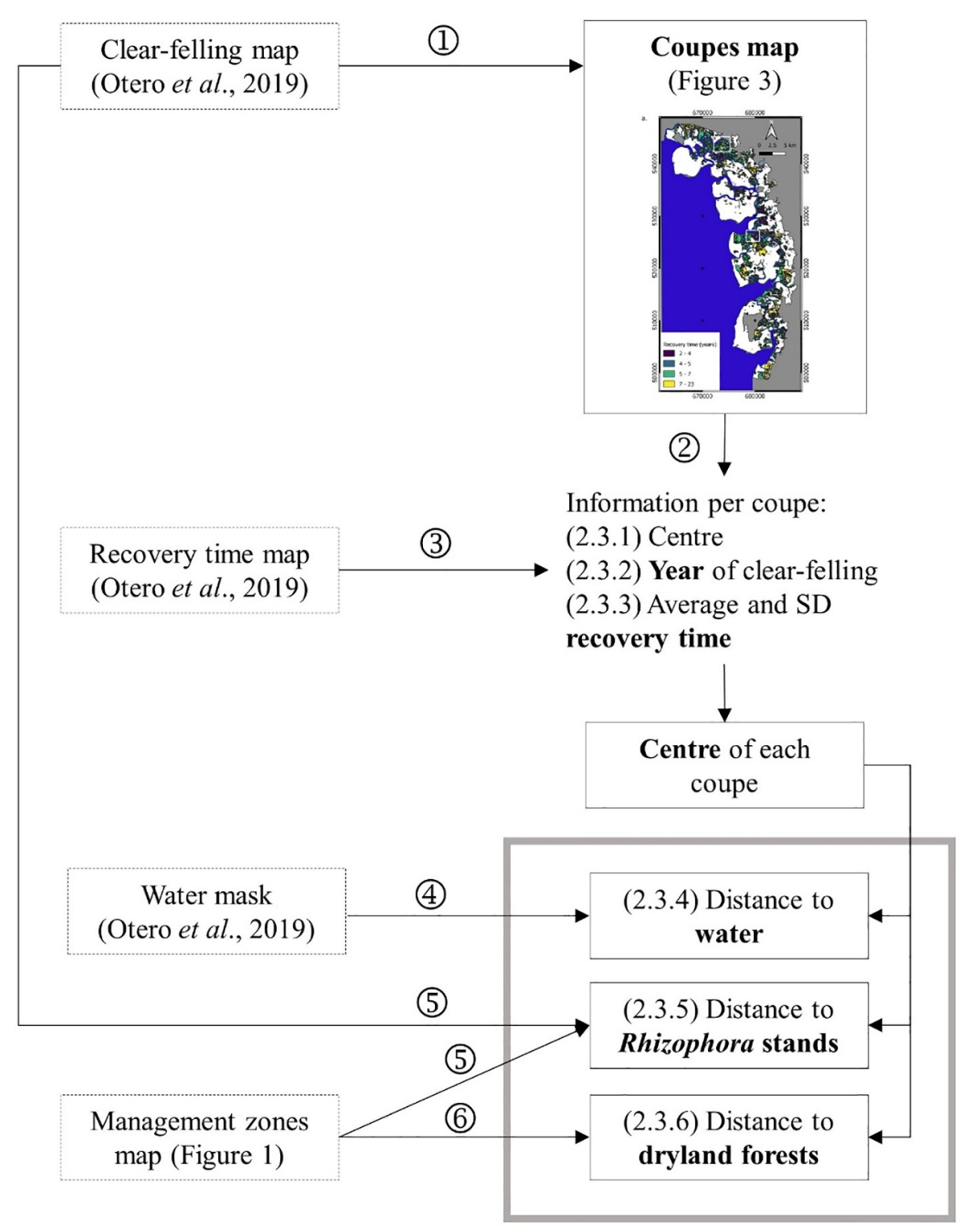

Fig. 2. Workflow followed to calculate the attributes of each coupe. The numbers in circles indicate the sequence followed to obtain the calculation of distances from each coupe to different types of landcover (grey square). The clear-felling map, the recovery time map and the water mask were taken from Otero et al. (2019). The management zones maps were digitized using the printed maps available in Ariffin and Mustafa (2013). These management zones maps indicate the location of the productive, restrictive productive, protective and unproductive zones, and the types of forests within the protective zones. The average and standard deviation (SD) of the recovery time per coupe were calculated using the summary statistics tool available in QGIS. The distances were calculated using the $v$.distance GRASS tool available in QGIS. The numbers between parentheses correspond to the steps explained in Section 2.3 .

Information per coupe:

restrictive productive forests that are mainly composed of Rhizophora species (Fig. 1a). We combined the previous two maps in a single map that contained the areas where Rhizophora stands were considered to be present, noting that some changes or differences might have occurred since their production and/or because of errors in mapping respectively. Afterwards, we removed the areas that were clear-felled between 1989 and 2015 based on the clear-felling map created by Otero et al. (2019). The result was a layer that contains the Rhizophora stands of the reserve that were not clear-felled between 1989 and 2015 .

2.3.6. The distance to the closest dryland forest stand within the protective zones based on the management plan map that describes the protective zones (Fig. 1b). All the distance variables were calculated using the $v$.distance tool from GRASS available in QGIS (QGIS Development Team, 2018).

We used the centres of each coupe as a proxy for its location, thereby minimizing border effects. Additionally, we found cases where the distance from a coupe centre to a Rhizophora stand or to dryland forest stands was zero and we removed these cases from further analyses (3\% of the cases in total). These cases were $1.3 \%$ of all the centres for the distances to Rhizophora stands and $1.6 \%$ for the distances to dryland forest stands. In the case of the Rhizophora forests, the centre of the coupe was outside the corresponding coupe because the original coupe had an irregular shape and the centre was located inside another Rhizophora stand. In the cases for the dryland forest stands, we found coupes that were clear-felled in areas that, according to the management plan, are protective zones comprised of dryland forests.

\subsection{Spatial context analysis}

\subsubsection{Univariate analysis}

We calculated four quartiles (25\%, 50\%, 75\% and 100\%) of the (i) average and (ii) standard deviation of the recovery time per coupe. We compared the distribution of these four quartiles for each of the distances calculated: to water, Rhizophora stands, and dryland forest stands. Medians of each quartile group of the recovery time were compared using the Wilcoxon Rank test because each quartile did not have a normal distribution (Shapiro-Wilk test, $p$-value $<0.0001$ ) for the average and standard deviation groups. These analyses were performed in RStudio version 1.1.456, R version 3.6.1 (RStudio Team, 2016).

We repeated the previous analyses by grouping quartiles of similar average time and standard deviation of the recovery time. We grouped 
the first, second and third quartiles (i.e. 25\%, 50\% and 75\%) into one group. A second group was defined that corresponded to the fourth quartile (highest $25 \%$ values). Medians of each quartile group of the recovery time were compared using the Wilcoxon Rank test. We used this statistical test because the distribution of each group did not have a normal distribution (Shapiro-Wilk test, $p$-value $<0.0001$ ).

\subsubsection{Multivariate analysis}

We used Generalized Least Squares (GLS) models to evaluate the relationship between the recovery time and the distance to different types of land cover. GLS models can be used when neighbouring values of the response variable, in our case the recovery time of each coupe, are correlated (Crawly, 2007). Spatial autocorrelation is typically observed in mapped data and it measures how similar areas are with their neighbouring areas in space (Crawly, 2007, Cliff and Ord, 1970). Therefore, it was necessary to use GLS to account for the spatial autocorrelation of the recovery time of neighbouring coupes.

We tested the relationship of the distance to water bodies, dryland forest stands and remaining Rhizophora stands in the average and standard deviation of the recovery time per coupe using two models (Eqs. (2) and (3)):

(i) Average Recovery time $=f$ (distance to water,

distance to dryland forest stands, distance to Rhizophora stands)

\section{(ii) Standard deviation Recovery time}

$=f$ (distance to water , distance to dryland forest stands, distance to Rhizophora stands)

Both models were corrected for spatial autocorrelation by using a Gaussian structure in each one. Additionally, the Nagelkerke adjusted $\mathrm{R}^{2}$ was reported for each model (Magee, 1990, Nagelkerke, 1991). These statistical analyses were performed in RStudio version 1.1.456, R version 3.6.1, using the stats, nlme and rcompanion packages (RStudio Team, 2016).

\section{Results}

\subsection{Distance calculation}

The spatial distribution of forests that were cleared in the same year (and hence identified as coupes) and their associated recover times based on the NDMI time-series is shown in Fig. 3. Only the coupes that recovered by 2015 are included in this study (i.e. 3127 coupes). In total, 10,943 ha were clear-felled and for each coupe, the NDMI recovered to the values observed prior to clearing. The average recovery time taking into account all the coupes (by 2015) was $5.6 \pm 2.4$ years. The median recovery time (interquartile range) was 5 years (4-7 years). The minimum recovery time was 2 years and the maximum was 23 years. Only two coupes had a recovery time of 23 years, which correspond to 0.36 ha in total.

The distance calculation to the closest forest stands and the closest water body is shown in Fig. 4 and supplementary data S1 and S2. The closest forest stand could be a patch of dryland forest in the protective zones (supplementary material S2), or a Rhizophora stand in the productive, restrictive productive or protective zones (supplementary material S1).

\subsection{Spatial context analysis}

\subsubsection{Univariate analysis}

3.2.1.1. Univariate analysis for the average recovery time. The average recovery time distribution was grouped in its corresponding four quartiles. Based on those four groups, the distances to the different types of land cover were analysed (supplementary data Fig. S3, Table
S2 and Table S3). Afterwards, we regrouped the quartiles into two new groups: the fast and the slow recovery time. The fast group included the first, second and third quartile, meaning that, coupes that recovered between 2 and 6.86 years. The slow group corresponded to the fourth quartile, with these associated with coupes that recovered between 6.87 and 23 years. We compared the fast and slow groups to the distances to the Rhizophora stands, the dryland forest stands and to the water (Fig. 5). A positive relationship with distance was observed in certain locations, with faster recoveries associated with coupes that were closer to water and Rhizophora stands (Fig. 5a, c). It is noteworthy that the difference in the median distance to Rhizophora stands between fast and slow recovery coupes was relatively small $(30 \mathrm{~m}$ and $33.5 \mathrm{~m}$ respectively). By contrast, coupes that were closer to dryland forest stands experienced slower recovery times (Fig. 5b).

We further analysed the differences between the fast and the slow recovery groups. Based on the Wilcoxon Rank Sum Test, a statistically significant difference was observed at the 0.05 level between the fast and the slow group for the distance to water bodies, dryland forest stands and the nearest Rhizophora stand (see Fig. 5).

3.2.1.2. Univariate analysis for the standard deviation of the recovery time. The standard deviation of the recovery time was analysed based on the four quartiles of its distribution (supplementary data Fig. S4, Table S4 and Table S5). The median value of the standard deviation (interquartile range) of the recovery time was $0.8(0.42-1.47)$, the minimum standard deviation value was zero and the maximum 8.5 . We regrouped the quartiles into two new groups, with these experiencing low and high standard deviations of recovery times. The low group included the first, second and third quartile, with these being coupes with a standard deviation of the recovery time between zero and 1.47. The high group corresponded to the fourth quartile, meaning that, coupes in which the standard deviation varied from 1.48 to 8.5 . We compared the low and high standard deviation groups to the distances to Rhizophora stands, dryland forest stands and water (Fig. 6). The coupes that were closer to water and Rhizophora stands had a lower standard deviation in the recovery time (Fig. 6a, c). By contrast, the coupes that were closer to dryland forest stands had a higher standard deviation compared to the ones that were farther away (Fig. 6b).

We further analysed the differences between the low and high standard deviation groups. Based on the Wilcoxon Rank Sum Test, there is a statistically significant difference at the 0.05 level between the low and high standard deviation groups for the distances to water bodies, dryland forest stands and closest Rhizophora stand (Fig. 6).

\subsubsection{Multivariate analysis}

3.2.2.1. Multivariate analysis of the average recovery time. The first GLS model was used to test the significance of each type of distance to explain the differences in the average recovery time per coupe. Based on the model, the distance to water bodies, dryland forests and Rhizophora stands contributed significantly to the changes in the average recovery time at the 0.05 level (Table 1 ). Coupes closer to water bodies and Rhizophora stands regenerated at a faster rate, whilst those closer to dryland forest stands recovered slower than those further away.

3.2.2.2. Multivariate analysis of the standard deviation of the recovery time. The second GLS model was used to test the significance of each type of distance to explain the standard deviation of the recovery time per coupe. Based on the model, the distance to water bodies and Rhizophora stands contributed significantly to the changes in the standard deviation of the recovery time at the 0.05 level (Table 2). The closer a coupe was to water bodies or a Rhizophora stand, the lower the standard deviation in the recovery time per coupe. By contrast, the closer a coupe was to a dryland forest stand, the higher the standard deviation in the recovery time per coupe. 
a.

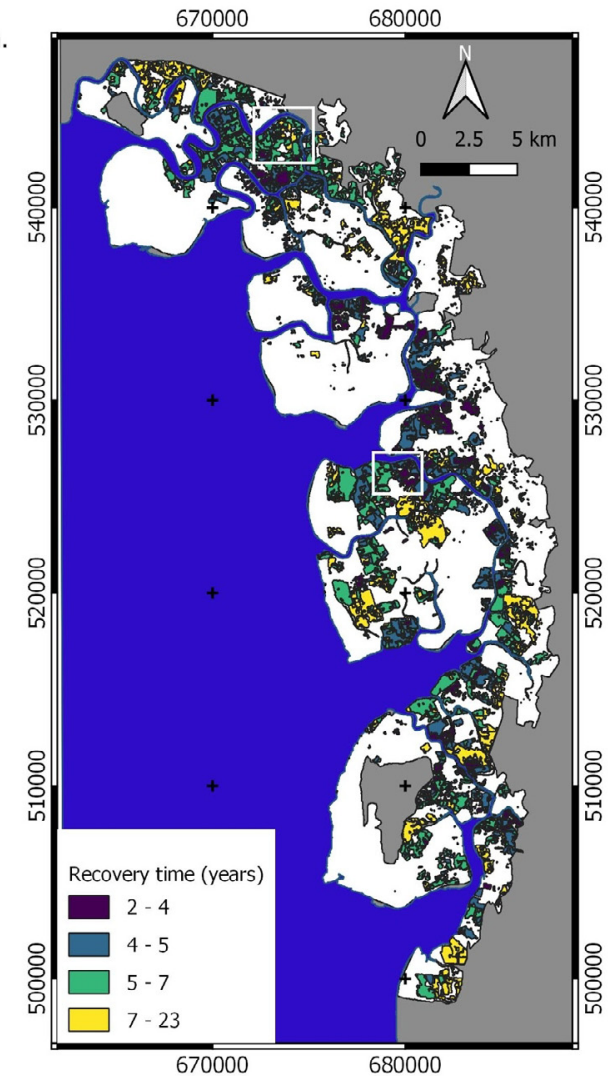

b.
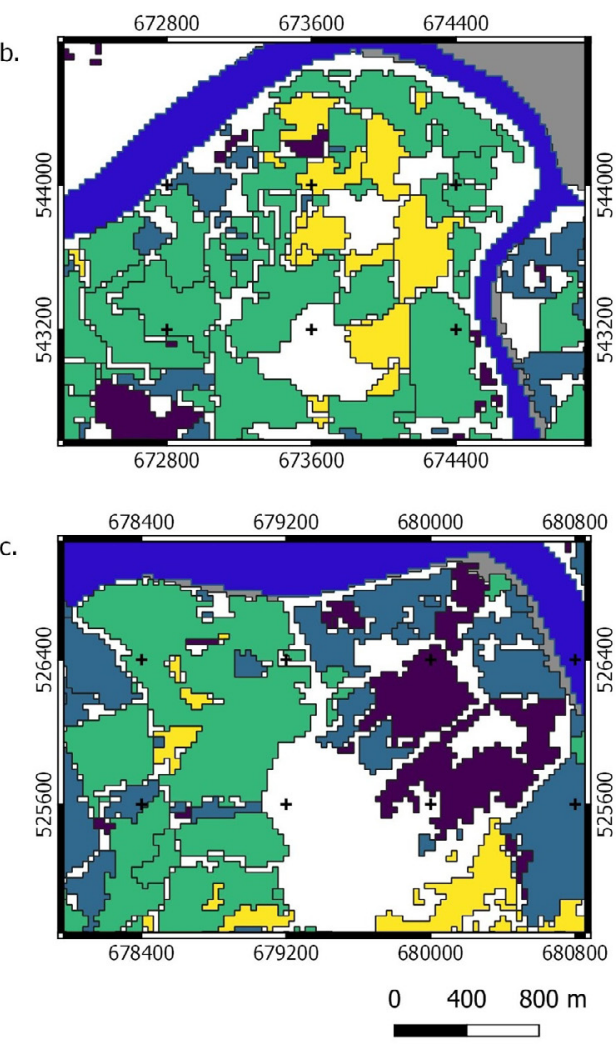

Fig. 3. Map of the coupes that represent the areas of the forest that were clear felled in the same year (a). The black lines indicate the borders of each coupe. The colours indicate the recovery time per coupe grouped by quartiles. Two detailed views of the areas indicated with a white rectangle in the top (b) and another white rectangle in the centre (c) are shown. The grey areas are outside the reserve. The white areas indicate places where no clear-felling events were detected or areas that were clear-felled but did not completely recover by 2015 .
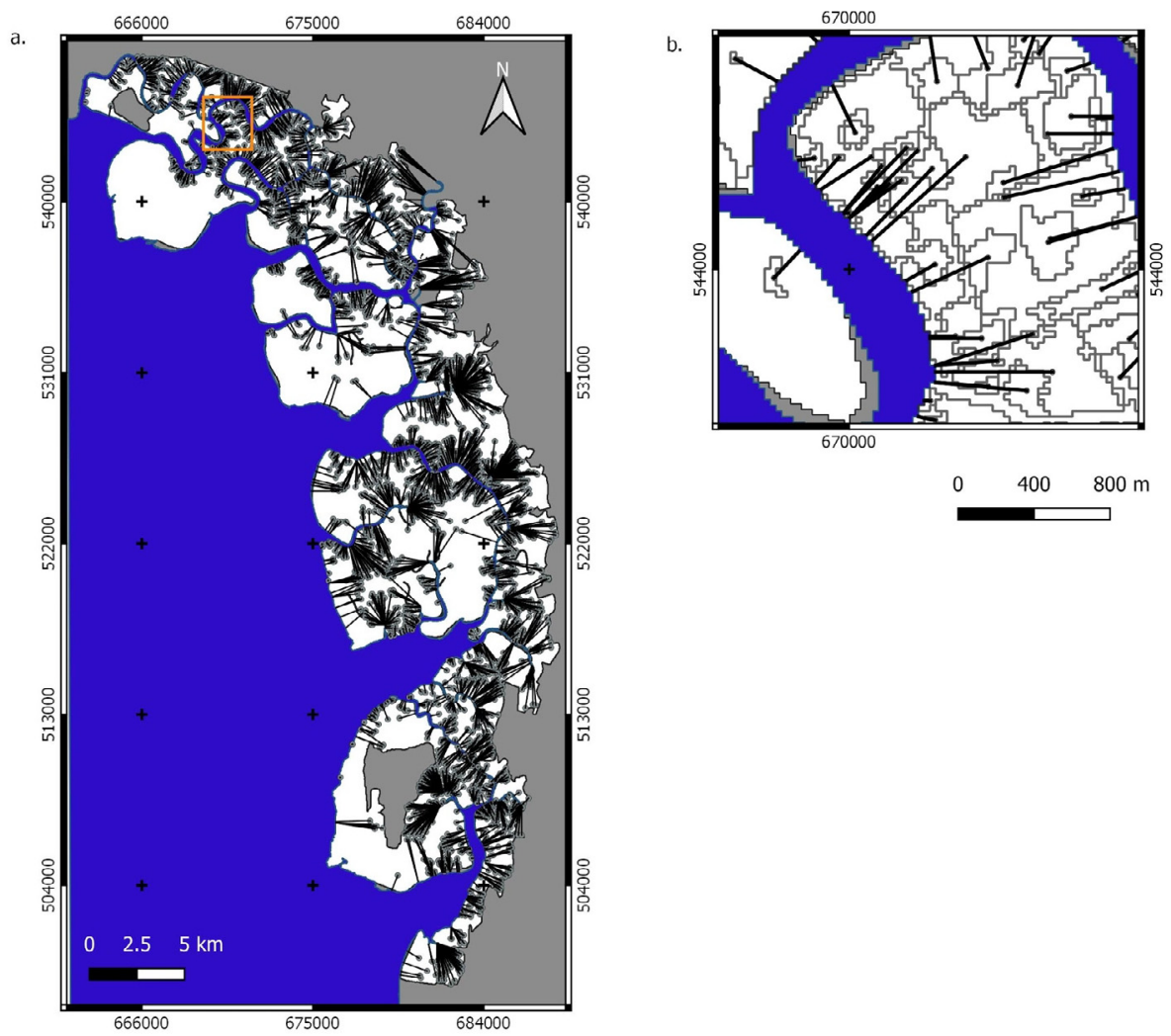

Fig. 4. The distance calculation from the centres of each coupe to the closest water body indicated in blue. The black lines indicate the shortest distance to a water body, the points indicate the centre of each coupe and the grey lines the borders of the coupes. The grey areas are outside the reserve. (b) A detailed view is shown which correspond to the orange square indicated in a. The area of the reserve is indicated in white. (For interpretation of the references to colour in this figure legend, the reader is referred to the web version of this article.) 
a.

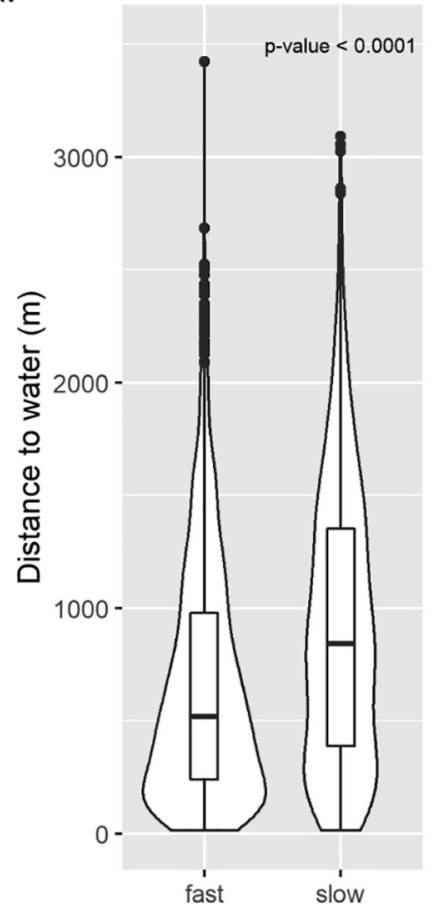

b.

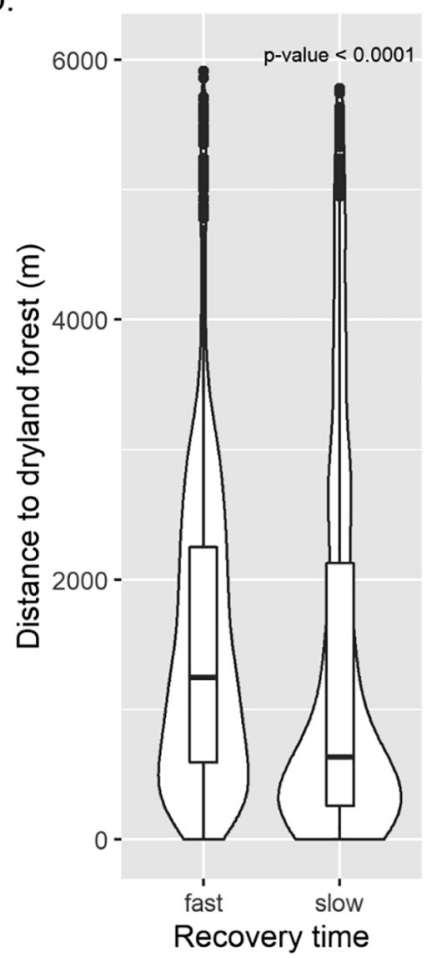

C.

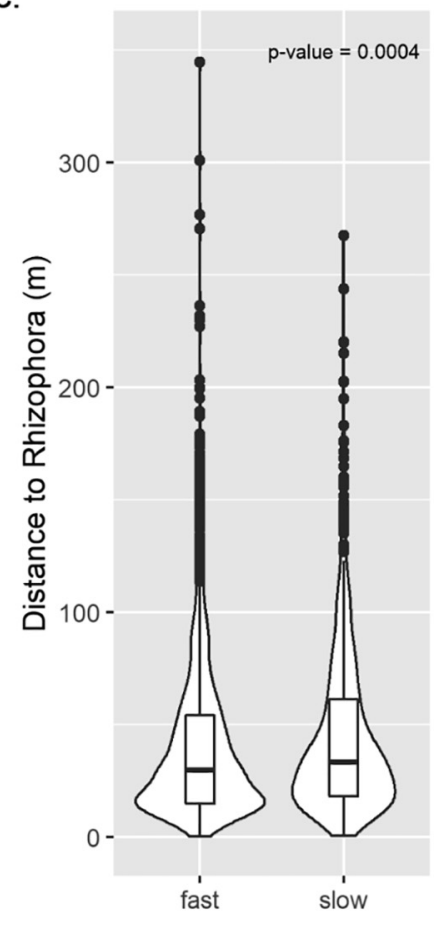

Fig. 5. The box plots and the probability distribution of the average recovery time groups. The relationship between the fast and slow recovery time groups and the distance to (a) water bodies, (b) dryland forest stands and (c) Rhizophora stands (c) are shown. The fast recovery time group are coupes that recovered between 2 and 6.86 years, and the slow recovery time group are coupes recovered between 6.87 and 23 years. The $p$-value is indicated for the comparison between the median distance of the fast and slow recovery time groups for each type of land cover.

a.

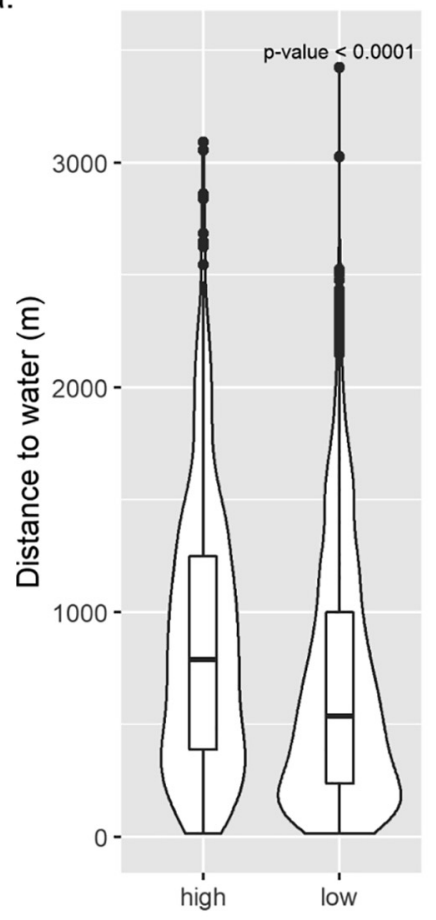

b.

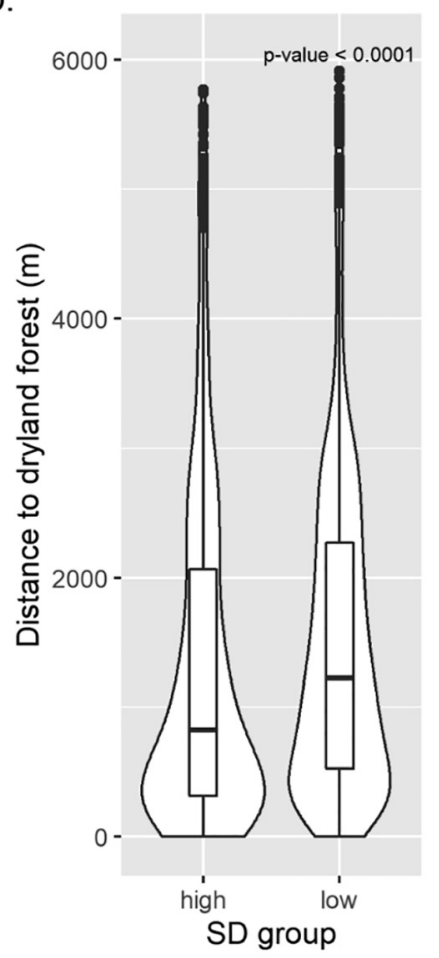

C.

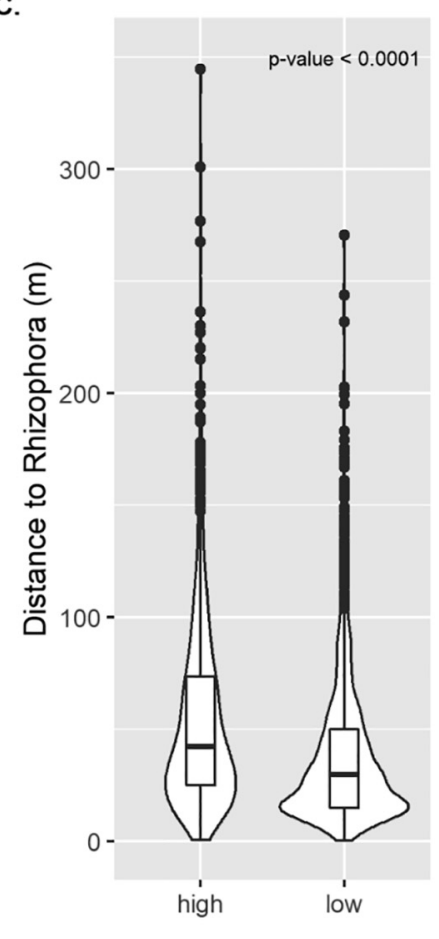

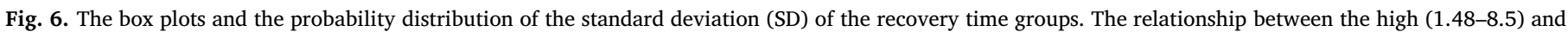
low (0-1.47) standard deviation of the recovery time groups and the distance to (a) water bodies, (b) dryland forest stands and (c) Rhizophora stands are shown. The $p$-value is indicated for the comparison between the median distance of the high and low standard deviation of the recovery time groups for each type of land cover. 
Table 1

GLS model results for the average recovery time. This model was corrected for spatial autocorrelation using a Gaussian structure (Adjusted $\mathrm{R}^{2}$ Nagelkerke $=0.061$ ).

\begin{tabular}{llc}
\hline Variable & Coefficient & p-value \\
\hline Distance to water $(\mathrm{km})$ & $0.896 \pm 0.073$ & $<0.0001$ \\
Distance to dryland forest stands $(\mathrm{km})$ & $-0.066 \pm 0.033$ & $\begin{array}{c}0.042 \\
<0.0001\end{array}$ \\
Distance to Rhizophora stands $(\mathrm{km})$ & $7.866 \pm 1.127$ & $<$ \\
\hline
\end{tabular}

\section{Table 2}

GLS model results for the standard deviation of the recovery time. This model was corrected for spatial autocorrelation using a Gaussian structure (Adjusted $\mathrm{R}^{2}$ Nagelkerke $=0.069$ ).

\begin{tabular}{llc}
\hline Variable & Coefficient & p-value \\
\hline Distance to water $(\mathrm{km})$ & $0.245 \pm 0.053$ & $<0.0001$ \\
Distance to dryland forest stands $(\mathrm{km})$ & $-0.034 \pm 0.027$ & $\begin{array}{c}0.2027 \\
<0.0001\end{array}$ \\
Distance to Rhizophora stands $(\mathrm{km})$ & $6.497 \pm 0.47$ & $<0.47$ \\
\hline
\end{tabular}

\section{Discussion}

\subsection{Distance calculation}

In this study we calculated the distance between the centres of areas that were clear-felled in the same year (i.e., coupes) and three different types of land cover: water bodies, dryland forest stands and Rhizophora stands. Two important considerations were made in order to calculate these distances. (i) First, this study used coupes (i.e., areas that were clear-felled in the same year) as the unit of analysis. We can rely in the information aggregated by coupes instead of pixels, as the average recovery time based on coupes is similar to the average recovery time using pixels as unit of analysis $(5.6 \pm 2.4$ years based on coupes vs. $5.9 \pm 2.7$ years based on pixels) (Otero et al., 2019). (ii) Second, the recovery time calculation was based on the NDMI, with this indicative of percentage canopy cover (Lucas et al., 2020). Therefore, it is only describing the behaviour of the first years of regeneration as vegetation indices saturate in dense vegetation (Baret and Guyot, 1991, Huete et al., 2002, Jackson et al., 2004). Nevertheless, we were able to capture differences in the recovery time prior to the saturation of the index and establish a relationship between these differences and the distance to different types of land cover such as water bodies, dryland forest stands and Rhizophora stands.

\subsection{Spatial context analysis}

We found a relationship between the average and standard deviation of the recovery time per coupe and the proximity to (i) water bodies, (ii) dryland forest stands and (iii) Rhizophora stands. (i) The closer a coupe was to water, the faster the regeneration compared to the coupes that were farther away. Mangrove propagules are dispersed by water (Tomlinson, 2016) and can be carried towards the edges of a water body by the direction of the water runoff (Di Nitto et al., 2013, Sousa et al., 2007). Therefore, propagules can more easily accumulate and establish on areas that are closer to the borders of water bodies. This phenomenon could also explain why the closer a coupe is to a water body, the lower the standard deviation of the recovery time within the coupe compared to those farther away. Although the propagules could also be washed away by tides, they can be trapped by vegetation and remain on land (Chang et al., 2008, Di Nitto et al., 2008, Di Nitto et al., 2013), which seems to be the case in our study area. Hickey et al., (2018) also observed the positive effect of the proximity to water in mangrove tree growth. They found that the closer a mangrove stand was to the water, the taller the trees compared to stands located further away from water bodies. As a result, higher estimates of biomass and carbon were observed in stands located closer to the water (Hickey et al., 2018).

(ii) Coupes closer to dryland forest stands regenerated at a slower rate compared to those farther away. Dryland forests are occasionally inundated by equinoctial tides and occur in more elevated soils on the landward side of the reserve (Ariffin and Mustafa, 2013, p. 30). Komiyama et al. (1996) and Sousa et al. (2007) reported lower establishment success of Rhizophora propagules at higher elevations due to higher soil hardness and difficulties for propagule rooting due to water standing in higher elevations. The topographic conditions in the dryland forests may not be suitable for establishment of Rhizophora propagules or these may be washed away by tides or freshwater discharge to lower elevation sites (Dahdouh-Guebas et al., 2000, Di Nitto et al, 2008, Di Nitto et al., 2013, Sousa et al., 2007). We also found that coupes closer to dryland forest stands had higher standard deviation in the recovery time within the coupe as compared to those farther away. Komiyama et al. (1996) reported that even small changes in topography, such as $35 \mathrm{~cm}$, have an impact on Rhizophora propagule establishment. Therefore, variations in elevation within a coupe could already have an impact on the spatial patterns of propagule establishment (Di Nitto et al., 2008, Sousa et al., 2007).

(iii) Patches of Rhizophora trees were always found close to clearfelled areas and therefore a natural supply of mangrove propagules was possible (see supplementary material S1). The availability of propagules from adjacent mangrove stands is one of the key elements to ensure propagule dispersal (Bosire et al., 2008, Di Nitto et al., 2008). Moreover, we found that the standard deviation of the recovery time within a coupe was lower if that coupe was closer to a Rhizophora stand. Rhizophora propagules do not move by large distances from the parental tree, changing location from 2 to $20 \mathrm{~m}$ (Chan and Husin, 1985, Sousa et al., 2007). The difference in the median distance from a Rhizophora stand for the coupes that recovered with a lower standard deviation as compared to the ones with higher standard deviation was $12 \mathrm{~m}$. This small change in distance can explain the differences in the variability in recovery times within a coupe. Although mangrove propagules are hydrochorous and could potentially travel large distances, the average travel inside mature stands could be small (Sousa et al., 2007).

The relationships that we found between the recovery time and the proximity to different types of land cover based on the univariate analysis coincided with the results obtained with the GLS models. The proximity to water and Rhizophora stands had a positive relationship with the recovery time between and within coupes. By contrast, proximity to dryland forest stands had a negative relationship with the recovery time between and within coupe. However, the explanatory power of the GLS models was very low. These models are only considering the proximity to different types of land cover to explain the recovery time. However, propagule dispersal and establishment are influenced by additional factors such as wind, currents, propagule predation, geomorphology, nutrient availability and salinity (Di Nitto et al., 2008, Di Nitto et al., 2013, Komiyama et al., 1996, Sousa et al., 2007; Tomlinson, 2016; Van der Stocken et al., 2015, Van Nedervelde et al, 2015). Though more studies are needed to further explain the influence of these factors on the variations of the recovery time, this study can guide the definition of new research questions and planning of new field studies that contribute to the understanding of the changes in the recovery patterns in the MMFR.

\subsection{Implication for the local management}

We found a relationship between the recovery time and the distance to different types of land cover. These insights about the regeneration of mangrove forests in the MMFR could guide future strategies implemented by the local management, in particular the evaluation of the current replantation policy of the reserve. The current policy is to replant areas two years after clear-cutting if natural regeneration is less than $70 \%$ in a specific area. Replantation consists of planting 
propagules or potted seedlings. Our results could be used in follow up studies to link the areas that required replanting, based on the records of the local management, with the coupes identified in this study and further analyse if there is an effect of replantation of propagules in the recovery time. Also, future decisions on the distribution of productive and protective zones in the reserve can be guided by this study. For example, by considering the proximity to water and dryland forest stands, the distribution of productive zones can be planned to ensure a proper regeneration of mangrove stands after clear-felling. Additional, areas that are more prone to have lower regeneration rates, could be managed in a different way, for example, by changing the type of management zone from productive to protective.

We found clear-felling events in $18 \%$ of the area indicated by the local management to be dryland forest stands and $12 \%$ in the area of Rhizophora protective stands. We created a digital version of the map of the protective zones by digitizing and georeferencing the map that describes the protective zones in the local management plan from 2010 to 2019. According to the local management, maps are updated for each management plan. For the last management plan (i.e. 2010 to 2019), a mosaic of two Satellite Pour l'Observation de la Terre (SPOT) images from 2007 and 2009 was used to update changes in the distribution of river channels, new infrastructure, erosion, accretion, and boundaries of Avicennia, Sonneratia and dryland forest stands (Ariffin and Mustafa, 2013, p. 33). However, we used Landsat annual time series from 1988 to 2015 to detect the clear-felling events and calculate the recovery time (Otero et al., 2019), including higher frequency of satellite observations. Therefore, we suggest incorporating the maps created in this study and include time-series of optical (Otero et al., 2019) and radar data (Lucas et al., 2020) to provide new information on the changes in the reserve that cannot be captured by using a mosaic image.

Additionally, the changes that we observed in protective areas could be an indication that the current management plan maps require a more frequent monitoring and update in certain areas, which can be achieved by using optical and radar data (Otero et al., 2019, Lucas et al., 2020). Moreover, the last management plan reported the species composition of the dryland forest stands based on the study by Chan (1989). We found a relationship between the recovery of clear-felled areas and the location of the coupes. Therefore, we suggest that a reassessment of the current forest structure of the dryland forests is necessary, as well as a detailed study of the topography of the MMFR. This information is valuable to the local management as it can provide further guidelines to improve the management, in particular the replantation policy and conservation of protective zones.

Before this study, the quantification of the early recovery time was not available for the local management. The map of the coupes that indicates the average recovery time (Fig. 3) is a new tool that can guide the planning and evaluation of the current replantation policy. Moreover, the recovery time map indicates the recovery time for the entire area of the reserve, a result that is difficult to attain using exclusively fieldwork methods given the logistical restrictions and costs that this latter approach will imply.

\section{Conclusions}

In this study we were able to identify the relationship between the recovery time of different coupes and the proximity to different types of land cover. We found a positive relationship with proximity to water and Rhizophora stands, meaning that, the closer a coupe was to a water body or Rhizophora stand, the faster it recovered from a clear-felling event as compared to coupes that were farther away. By contrast, there is a negative relationship between the proximity to dryland forest stands and the recovery time. These results can be used by the local management to plan and evaluate the current replantation policy, to guide monitoring activities in protective and productive zones, and to guide decisions on the distribution of the areas to be clear-felled in the future. This study recommends that satellite sensor data be more widely considered for mapping and monitoring the past and current dynamics of mangroves in the MMFR to assist management.

\section{Funding}

This research was funded by BELSPO (Belgian Science Policy Office) in the frame of the STEREO III Programme - Project Managing Mangrove Forests with Optical and Radar Environmental Satellites (MAMAFOREST) grant number SR/00/323. The European Regional Development Fund (ERDF) Ser Cymru program is also thanked for funding Prof. Lucas.

\section{CRediT authorship contribution statement}

Viviana Otero: Conceptualization, Methodology, Validation, Formal analysis, Investigation, Writing - original draft, Writing - review \& editing. Richard Lucas: Conceptualization, Validation, Writing review \& editing, Supervision, Resources, Project administration, Funding acquisition. Ruben Van De Kerchove: Writing - review \& editing, Supervision, Data curation, Resources, Project administration, Funding acquisition. Behara Satyanarayana: Writing - review \& editing, Supervision, Validation, Resources, Project administration, Funding acquisition. Husain Mohd-Lokman: Resources, Project administration, Funding acquisition. Farid Dahdouh-Guebas: Conceptualization, Validation, Writing - review \& editing, Supervision, Resources, Project administration, Funding acquisition.

\section{Acknowledgments}

We would like to thank the Perak State Forestry Department and the local rangers of the MMFR for their support during the fieldwork and for providing the management plans of the reserve. This study was carried out with the approval of the Perak State Forestry Department, Ipoh, Malaysia.

\section{Declaration of Competing Interest}

The authors declared that there is no conflict of interest.

\section{Appendix A. Supplementary material}

Supplementary data to this article can be found online at https:// doi.org/10.1016/j.foreco.2020.118213.

\section{References}

Alongi, Daniel M, 2012. Carbon sequestration in mangrove forests. Carbon Manage. 3 (3), 313-322.

Amir, A. Aldrie, 2012. Canopy gaps and the natural regeneration of Matang mangroves. For. Ecol. Manage. 269, 60-67. https://linkinghub.elsevier.com/retrieve/pii/ S0378112711007870.

Ariffin, R., Mustafa, N.M.S.N., 2013. A Working Plan for the Matang Mangrove Forest Reserve, Perak (6th revision). State Forestry Department of Perak, Malaysia.

Aslan, Aslan, Rahman, Abdullah F., Warren, Matthew W., Robeson, Scott M., 2016. Mapping spatial distribution and biomass of coastal wetland vegetation in Indonesian Papua by combining active and passive remotely sensed data. Remote Sens. Environ. 183, 65-81. https://linkinghub.elsevier.com/retrieve/pii/S0034425716301900.

Asthon, E.C., Hogart, P.J., Ormond, R., 1999. Breakdown of mangrove leaf litter in a managed mangrove forest in Peninsular Malaysia. Hydrobiologia 413, 77-88.

Abdul Aziz, A.A., Phinn, Stuart, Dargusch, Paul, 2015. Investigating the decline of ecosystem services in a production mangrove forest using Landsat and object-based image analysis. Estuar. Coast. Shelf Sci. 164, 353-366. https://linkinghub.elsevier. $\mathrm{com} /$ retrieve/pii/S0272771415300548.

Aziz, Ammar Abdul, Thomas, Sebastian, Dargusch, Paul, Phinn, Stuart, 2016. Assessing the potential of REDD + in a production mangrove forest in Malaysia using stakeholder analysis and ecosystem services mapping. Marine Policy 74, 6-17. https:// linkinghub.elsevier.com/retrieve/pii/S0308597X16303748.

Baret, F., Guyot, G., 1991. Potential and limits of vegetation indices for LAI and APAR Assessment. Remote Sens. Environ. 35, 161-173.

Bosire, J.O., Dahdouh-Guebas, F., Walton, M., Crona, B.I., Lewis III, R.R., Field, C., Kairo, J.G., Koedam, N., 2008. Functionality of restored mangroves: A review. Aquat. Bot. 
89 (2), 251-259. https://linkinghub.elsevier.com/retrieve/pii/ S0304377008000521.

Bosire, J.O., Kairo, J.G., Kazungu, J., Koedam, N., Dahdouh-Guebas, F., 2005. Predation on propagules regulates regeneration in a high-density reforested mangrove plantation. Mar. Ecol. Prog. Ser. 299, 149-155.

Bunting, P., Rosenqvist, A., Lucas, R.M., Rebelo, L., Hilarides, L., Thomas, N., Hardy, A., Itoh, T., Shimada, M., Finlayson, C.M., 2018. The Global Mangrove Watch - A New 2010 Global Baseline of Mangrove Extent. Remote Sensing 10 (10), 1669. https://doi. org $/ 10.3390 / \mathrm{rs} 10101669$.

Camarretta, N., Puletti, N., Chiavetta, U., Corona, P., 2017. Quantitative changes of forest landscapes over the last century across Italy. Plant Biosystems 152 (5), 1011-1019.

Chan, H.T., Husin, N., 1985. Propagule dispersal, establishment, and survival of Rhizophora mucronata. Malaysian For. 48, 324-329.

Chang, E.R., Veeneklaas, R.M., Buitenwerf, R., Bakker, J.P., Bouma, T.J., 2008. To move or not to move: determinants of seed retention in a tidal marsh. Funct. Ecol. 22, $720-727$.

Chan, H.T., 1989. A note on tree species productivity of a natural dryland mangrove forest in Matang, Peninsular Malaysia. J. Trop. For. Sci. 1 (4), 399-400.

Chong, V.C., 2006. Sustainable utilization and management of Mangrove ecosystems of Malaysia. Aquat. Ecosyst. Health Manage. 9 (2), 249-260.

Cliff, Andrew D., Ord, Keith, 1970. Spatial Autocorrelation: A Review of Existing and New Measures with Applications. Econ. Geogr. 46, 269. https://www.jstor.org/stable/ 143144 ? origin $=$ crossrefhttps: $/ /$ doi.org $/ 10.2307 / 143144$.

Conchedda, G., Durieux, L., Mayaux, P., 2008. An object-based method for mapping and change analysis in mangrove ecosystems. ISPRS J. Photogramm. Remote Sens. 63 (5), 578-589. https://doi.org/10.1016/j.isprsjprs.2008.04.002.

Crawly, M.J., 2007. The R Book. John Wiley \& Sons Ltd, England, pp. 774-785.

Dahdouh-Guebas, F., Verheyden, A., De Genst, W., Hettiarachchi, S., Koedam, N., 2000 Four decade vegetation dynamics in Sri Lankan mangroves as detected from sequential aerial photography : a case study in Galle. Bull. Mar. Sci. 67 (2), 741-759.

Dahdouh-Guebas, F., Collin, S., Lo Seen, D., Rönnbäck, P., Depommier, D., Ravishankar, T., Koedam, N., 2006. Analysing ethnobotanical and fishery-related importance of mangroves of the East-Godavari Delta (Andhra Pradesh, India) for conservation and management purposes. J. Ethnobiol. Ethnomed. 2, 24.

Di Nitto, D., Dahdouh-Guebas, F., Kairo, J.G., Decleir, H., Koedam, N., 2008. Digital terrain modelling to investigate the effects of sea level rise on mangrove propagule establishment. Mar. Ecol. Prog. Ser. 356, 175-188. http://www.int-res.com/ abstracts/meps/v356/p175-188/.

Di Nitto, D., Erftemeijer, P.L.A., van Beek, J.K.L., Dahdouh-Guebas, F., Higazi, L., Quisthoudt, K., Jayatissa, L.P., Koedam, N., 2013. Modelling drivers of mangrove propagule dispersal and restoration of abandoned shrimp farms. Biogeosciences 10 , 5095-5113.

Donato, D.C., Kauffman, J.B., Murdiyarso, D., Kurnianto, S., Stidham, M., Kanninen, M., 2011. Mangroves among the most carbon-rich forest in the tropics. Nat. Geosci. 4, 293-297.

Duke, Norman C., Ball, Marilyn C., Ellison, Joanna C., 1998. Factors Influencing Biodiversity and Distributional Gradients in Mangroves. Global Ecology and Biogeography Letters 7 (1), 27. https://www.jstor.org/stable/2997695?origin = crossrefhttps://doi.org/10.2307/2997695.

Ellison, Aaron M., 2000. Mangrove Restoration: Do We Know Enough? Restor. Ecol. 8 (3), 219-229.

FAO, 1994. Mangrove forest management guidelines. FAO Forestry Paper 117. Retrieved from http://www.fao.org/docrep/016/ap428e/ap428e00.pdf [April, 2020].

Feller, Ilka C., Friess, Daniel A., Krauss, Ken W., Lewis III, Roy R., 2017. The state of the world's mangroves in the 21st century under climate change. Hydrobiologia 803 (1), 1-12. http://link.springer.com/10.1007/s10750-017-3331-z.

Friess, Daniel A., Thompson, Benjamin S., Brown, Ben, Amir, A. Aldrie, Cameron, Clint, Koldewey, Heather J., Sasmito, Sigit D., Sidik, Frida, 2016. Policy challenges and approaches for the conservation of mangrove forests in Southeast Asia: Conservation of Mangrove Forests. Conserv. Biol. 30 (5), 933-949.

Gao, Bo-cai, 1996. NDWI-A normalized difference water index for remote sensing of vegetation liquid water from space. Remote Sens. Environ. 58 (3), 257-266. https:// linkinghub.elsevier.com/retrieve/pii/S0034425796000673.

Goessens, A., Satyanarayana, B., Van der Stocken, T., Quispe Zuniga, M., Moh-Lokman, H., Sulong, I., Dahdouh-Guebas, F., 2014. Is Matang Mangrove Forest in Malaysia sustainably rejuvenating after more than a century of conservation and harvesting management? PLOS ONE 9 (8).

Gong, W.K., Ong, J.E., 1995. The use of demographic studies in mangrove silviculture. Hydrobiologia 195, 255-261.

Hamunyela, Eliakim, Verbesselt, Jan, Herold, Martin, 2016. Using spatial context to improve early detection of deforestation from Landsat time series. Remote Sens. Environ. 172, 126-138. https://linkinghub.elsevier.com/retrieve/pii/ S0034425715301942.

Herold, Martin, Couclelis, Helen, Clarke, Keith C., 2005. The role of spatial metrics in the analysis and modeling of urban land use change. Comput. Environ. Urban Syst. 29 (4), 369-399. https://linkinghub.elsevier.com/retrieve/pii/S0198971503001145.

Hickey, S.M., Callow, N.J., Phinn, S., Lovelock, C.E., Duarte, C.M., 2018. Spatial complexities in aboveground carbon stocks of a semi-arid mangrove community: A remote sensing height-biomass-carbon approach. Estuar. Coast. Shelf Sci. 200, 194-201. https://linkinghub.elsevier.com/retrieve/pii/S0272771417307229.

Huete, A., Didan, K., Miura, T.., Rodriguez, E.P., Gao, X., Ferreira, L.G., 2002. Overview of the radiometric and biophysical performance of the MODIS vegetation indices. Remote Sens. Environ. 83 (1-2), 195-213. https://linkinghub.elsevier.com/retrieve/ pii/S0034425702000962.

Jackson, T.J., Che, D., Cosh, M., Li, F., Anderson, M., Walthall, C., Doriaswamy, P., Hunt, E.R., 2004. Vegetation water content mapping using Landsat data derived normalized difference water index for corn and soybeans. Remote Sens. Environ. 92, 475-482.

Kairo, J.G., Dahdouh-Guebas, F., Bosire, J., Koedam, N., 2001. Restoration and management of mangrove systems - a lesson for and from the East African region. S. Afr. J. Bot. 67 (3), 383-389. https://linkinghub.elsevier.com/retrieve/pii/ S0254629915311534.

Koch, Evamaria W, Barbier, Edward B, Silliman, Brian R, Reed, Denise J, Perillo, Gerardo ME, Hacker, Sally D, Granek, Elise F, Primavera, Jurgenne H, Muthiga, Nyawira, Polasky, Stephen, Halpern, Benjamin S, Kennedy, Christopher J, Kappel, Carrie V, Wolanski, Eric, 2009. Non-linearity in ecosystem services: temporal and spatial variability in coastal protection. Front. Ecol. Environ. 7 (1), 29-37.

Komiyama, Akira, Santiean, Tanuwong, Higo, Mutsuki, Patanaponpaiboon, Pipat, Kongsangchai, Jitt, Ogino, Kazuhiko, 1996. Microtopography, soil hardness and survival of mangrove (Rhizophora apiculata BL.) seedlings planted in an abandoned tin-mining area. For. Ecol. Manage. 81 (1-3), 243-248. https://linkinghub.elsevier. com/retrieve/pii/0378112795035915.

Lewis III, Roy R., 2005. Ecological engineering for successful management and restoration of mangrove forests. Ecol. Eng. 24 (4), 403-418. https://linkinghub.elsevier.com/ retrieve/pii/S092585740500042X.

López-Portillo, J. Lewis III, R.R. Saenger, P., Rovai, A., Koedam, N., Dahdouh-Guebas, F., Agraz-Hernández, C. and Rivera-Monroy, V.H., 2017. Mangrove Forest Restoration and Rehabilitation. In: Rivera-Monroy et al. (Eds.), Mangrove Ecosystems: A Global biogeographic Perspective. Springer International Publishing, pp. 301-345. https:// doi.org/10.1007/978-3-319-62206-4_10.

Lucas, R., Van De Kerchove, R., Otero, V., Lagomasino, D., Fatoyinbo, T., Omar, H. Satyanarayana, B., Dahdouh-Guebas, F., 2020. Structural characterization of mangrove forests achieved through combining multiple sources of Remote Sensing Data. Remote Sens. Environ. 237, 111543. https://doi.org/10.1016/j.rse.2019.111543.

Magee, L., 1990. $\mathrm{R}^{2}$ measures based on Wald and Likelihood Ratio Joint Significance Tests. Am. Statist. 44 (3), 250-253.

Mukherjee, N., Sutherland, W.J., Khan, M.N.I., Berger, U., Schmitz, N., Dahdouh-Guebas, F., Koedam, N., 2014. Using expert knowledge and modeling to define mangrove composition, functioning, and threats and estimate time frame of recovery. Ecol. Evol 4, 2247-2262.

Nagelkerke, N.J.D., 1991. A note on a general definition of the coefficient of determination. Biometrika 78 (3), 691-692.

Otero, V., Van De Kerchove, R., Satyanarayana, B., Mohd-Lokman, H., Lucas, R., Dahdouh-Guebas, F. 2019. An Analysis of the Early Regeneration of Mangrove Forests using Landsat Time Series in the Matang Mangrove Forest Reserve, Peninsular Malaysia. Remote Sens. 11 (7), 774. https://doi.org/10.3390/rs11070774\.

Peng, Yisheng, Diao, Junming, Zheng, Mingxuan, Guan, Dongsheng, Zhang, Renduo, Chen, Guizhu, Lee, Shing Yip, 2016. Early growth adaptability of four mangrove species under the canopy of an introduced mangrove plantation: Implications for restoration. For. Ecol. Manage. 373, 179-188. https://linkinghub.elsevier.com/ retrieve/pii/S0378112716302092.

Putz, Francis E., Chan, H.T., 1986. Tree growth, dynamics, and productivity in a mature mangrove forest in Malaysia. For. Ecol. Manage. 17 (2-3), 211-230. https:// linkinghub.elsevier.com/retrieve/pii/0378112786901131.

QGIS Development Team, 2018. QGIS Geographic Information System version 3.4.4 Madeira. Open Source Geospatial Foundation Project. http://qgis.osgeo.org.

Ribeiro, Milton Cezar, Metzger, Jean Paul, Martensen, Alexandre Camargo, Ponzoni, Flávio Jorge, Hirota, Márcia Makiko, 2009. The Brazilian Atlantic Forest: How much is left, and how is the remaining forest distributed? Implications for conservation. Biol. Conserv. 142 (6), 1141-1153. https://linkinghub.elsevier.com/retrieve/pii/ S0006320709000974.

Rivera-Monroy, Victor H., Twilley, Robert R., Medina, Ernesto, Moser, E. Barry, Botero, Leonor, Francisco, Ana Marta, Bullard, Evelyn, 2004. Spatial variability of soil nutrients in disturbed riverine mangrove forests at different stages of regeneration in the San Juan River estuary, Venezuela. Estuaries 27 (1), 44-57. http://link.springer. $\mathrm{com} / 10.1007 / \mathrm{BF} 02803559$.

RStudio Team, 2016. RStudio: Integrated Development for R. RStudio, Inc., Boston, USA. http://www.rstudio.com.

Saenger, P., 2002. Mangrove Ecology. Silviculture and Conservation. Kluwer Academic Publishers, Dordrecht, The Netherlands, pp. 229-243.

Sillanpää, Mériadec, Vantellingen, Juliana, Friess, Daniel A., 2017. Vegetation regeneration in a sustainably harvested mangrove forest in West Papua, Indonesia. For. Ecol. Manage. 390, 137-146. https://linkinghub.elsevier.com/retrieve/pii/ S0378112716309185.

Simard, Marc, Fatoyinbo, Lola, Smetanka, Charlotte, Rivera-Monroy, Victor H., Castañeda-Moya, Edward, Thomas, Nathan, Van der Stocken, Tom, 2019. Mangrove canopy height globally related to precipitation, temperature and cyclone frequency. Nature Geosci 12 (1), 40-45. http://www.nature.com/articles/s41561-018-0279-1.

Sousa, Wayne P., Kennedy, Peter G., Mitchell, Betsy J., 2003. Propagule size and predispersal damage by insects affect establishment and early growth of mangrove seedlings. Oecologia 135 (4), 564-575. http://link.springer.com/10.1007/s00442 003-1237-0.

Sousa, Wayne P., Kennedy, Peter G., Mitchell, Betsy J., Ordóñez L, Benjamín M., 2007. Supply-side ecology in mangroves: do propagule dispersal and seedling establishment explain forest structure? Ecol. Monogr. 77 (1), 53-76.

Spalding, M., Kainuma, M., Collins, L., 2010. Word Atlas of Mangroves. Earthscan, London, pp. 319

Suyadi, Gao, Jay, Lundquist, Carolyn J., Schwendenmann, Luitgard, 2018. Characterizing landscape patterns in changing mangrove ecosystems at high latitudes using spatial metrics. Estuar. Coast. Shelf Sci. 215, 1-10. https://linkinghub.elsevier.com/ retrieve/pii/S0272771418301082.

Tomlinson, P.B., 2016. The botany of mangroves, second ed. Cambridge University Press, UK, pp. 135-163. 
Van der Stocken, T., Vanschoenwinkel, B., De Ryck, D.J.R., Bouma, T.J., DahdouhGuebas, F., Koedam, N., 2015. Interaction between Water and Wind as a Driver of Passive Dispersal in Mangroves. PLoS ONE 10 (3). https://doi.org/10.1371/journal. pone. 0121593.

Van Nedervelde, Fleur, Cannicci, Stefano, Koedam, Nico, Bosire, Jared, Dahdouh-Guebas, Farid, 2015. What regulates crab predation on mangrove propagules? Acta
Oecologica 63, 63-70. https://linkinghub.elsevier.com/retrieve/pii/ S1146609X14001301.

Walters, B.B., Rönnbäck, P., Kovacs, J.M., Crona, B., Hussain, S.A., Badola, R., Primavera, J.H., Barbier, E., Dahdouh-Guebas, F., 2008. Ethnobiology, socio-economics and management of mangrove forest: A review. Aquat. Bot. 220-236. 